\title{
PEMBELAJARAN KOOPERATIF TIPE GROUP INVESTIGATION (GI) DENGAN METODE KNOW-WANT-LEARN (KWL): DAMPAK TERHADAP HASIL BELAJAR FLUIDA DINAMIS
}

\author{
Ria Astri Harahap ${ }^{1}$, Derlina ${ }^{2}$ \\ ${ }^{1,2}$ Pendidikan Fisika, Universitas Negeri Medan, Jl. Willem Iskandar Pasar V, Medan, Indonesia; \\ e-mail: ${ }^{1}$ riaastriharahap96@gmail.com; ${ }^{2}$ derlina.nst@gmail.com
}

Diterima: 9 Juni 2017. Disetujui: 27 September 2017. Dipublikasikan: 28 Oktober 2017

\begin{abstract}
Abstrak: Penelitian ini bertujuan untuk mengetahui pengaruh model pembelajaran kooperatif tipe $G I$ dengan metode Know-Want-Learn terhadap hasil belajar siswa. Jenis penelitian ini adalah quasi experiment dengan populasi seluruh siswa kelas XI SMA Negeri 21 Medan T.P. 2016/2017. Pengambilan sampel dilakukan dengan cara cluster random sampling. Instrumen yang digunakan dalam bentuk pilihan berganda dengan 5 pilihan jawaban sebanyak 15 soal. Kemudian pada kedua kelas diberikan perlakuan yang berbeda, kelas eksperimen dengan model pembelajaran kooperatif tipe GI dengan metode Know-WantLearn $(K W L)$ dan kelas kontrol dengan pembelajaran konvensional. Setelah pembelajaran selesai diberikan, diperoleh postes dengan nilai rata-rata hasil belajar siswa pada kelas eksperimen 74,7dan kelas kontrol 63,53. Berdasarkan hasil analisa perhitungan uji t, ada pengaruh model pembelajaran kooperatif tipe GI dengan metode Know-Want-Learn $(K W L)$ terhadap hasil belajar siswa pada materi pokok Fluida dinamis di kelas XI SMA Negeri 21 Medan T.P 2016/2017.
\end{abstract}

Kata kunci: hasil belajar, kooperatif tipe group investigation, model KWL

\section{GROUP INVESTIGATION (GI) COOPERATIVE LEARNING THROUGH THE KNOW-WANT-LEARN (KWL) METHOD: THE IMPACT ON DYNAMIC FLUID LEARNING OUTCOMES}

\begin{abstract}
This research purposes to know the effect learning cooperative model type GI with Know-WantLearn method toward the result of student learning. The type of research was quasi-experiment with the population in this research is all students in class XI SMA Negeri 21 Medan A.Y.2016/2017. Cluster random sampling technique took the sample. The instrument that used is multiple choice with five options answer as much as 15 items. Then two classes give different learning, experiment class with cooperative learning model type GI with Know-Want-Learn method and control class with conventional learning. After learning had been given, got post-test with average calculation value of student experiment class is 74,7 and control class is 63,53. Based on the results of calculation of t-test analysis, there is the effect learning model cooperative type GI with Know-Want-Learn method toward the result of student learning at the dynamic fluid topic in class XI SMA Negeri 21 Medan A.Y.2016/2017.
\end{abstract}

C 2017 Pendidikan Fisika, FTK UIN Raden Intan Lampung

Keywords: learning outcomes, cooperative group investigation type, KWL model.

\section{PENDAHULUAN}

Pendidikan yang bermutu, akan menghasilkan sumber daya manusia yang berkualitas dan berdaya saing tinggi. Salah satu persoalan yang belakangan ini dihadapi bangsa Indonesia adalah rendahnya kualitas pendidikan, baik pada tingkat dasar maupun tingkat menengah (Gumrowi, 2016). Pendidikan sebagai standar ukur peningkatan kehidupan masyarakat di era global harus dapat memberi dan memfasilitasi bagi tumbuh dan berkembangnya keterampilan intelektual, sosial, dan personal. Pendidikan diharapkan mampu membentuk individu-individu yang berkompetensi dibidangnya untuk menyongsong pembangunan bangsa 
dalam mengisi kemerdekaan (Santoso, 2015).

Sekolah sebagai institusi pendidikan perlu mengembangkan pembelajaran sesuai tuntutan kebutuhan era global. Pengalaman di lapangan membuktikan bahwa proses pembelajaran seringkali diperhadapkan dengan kendala-kendala teknis yang mengakibatkan ketegangan dan membuat penyampaian materi oleh guru bagi siswa membosankan (Yusuf \& Amin, 2016). Berdasarkan hal tersebut, pendidik harus mampu mendesain sistem pembelajaran yang mampu memotivasi dan meningkatkan keterampilan peserta didik karena hal tersebut akan berdampak pada keberhasilan siswa memahami konsep yang dipelajari (Erlinda, 2017; Komikesari, 2016; Wijayanti, Maharta, \& Suana, 2017).

Pesatnya perkembangan ilmu pengetahuan dan teknologi sekarang ini tidak dapat terlepas dari kemajuan ilmu fisika yang banyak menghasilkan temuan baru dalam bidang sains dan teknologi. Mata pelajaran fisika merupakan bagian dari sains yang membutuhkan pemahaman tingkat tinggi yang komprehensif (Sasmita, 2017). Fisika dalam hal ini ditempatkan sebagai salah satu mata pelajaran yang penting karena salah satu syarat penguasaan ilmu pengetahuan dan teknologi berhubungan dengan ilmu pengetahuan alam (IPA) yang di dalamnya termasuk fisika. Fisika merupakan suatu ilmu pengetahuan yang mempelajari gejala-gejala alam, yang berupa kumpulan fakta, konsep, prinsip, teori dan hukum serta proses yang sistematis serta dapat di uji kebenarannya dan dapat dimanfaatkan oleh manusia dalam keperluan hidupnya. Fisika merupakan objek mata pelajaran yang lebih menitikberatkan pada pemahaman daripada penghafalan siswa terhadap materi.

Berdasarkan keterangan guru di SMA Negeri 21 Medan, saat ujian semester ganjil yang dilakukan menunjukkan bahwa hanya 6 orang dari 34 orang yang berhasil mendapat nilai di atas kriteria ketuntasan minimal. Hal ini berarti $82 \%$ diantaranya masih memiliki hasil belajar fisika yang rendah. Selain wawancara dengan guru mata pelajaran fisika, pembagian angket kepada siswa juga dilakukan saat observasi awal. Dari angket yang diberikan kepada 32 responden, menunjukkan bahwa 93\% siswa menganggap bahwa pelajaran fisika itu adalah pelajaran yang sulit karena banyak rumus dan rumit. Berdasarkan hasil wawancara juga terlihat bahwa pembelajaran fisika didominasi oleh metode ceramah dan mencatat. Guru lebih berorientasi pada materi pelajaran dengan alasan tuntutan kurikulum yang harus tercapai untuk mempersiapkan peserta didik dalam menghadapi ulangan dan ujian. Hal ini didukung dengan hasil angket yang diberikan kepada 32 responden, $89 \%$ siswa menginformasikan bahwa pelajaran yang dilakukan di kelas dengan metode ceramah, mencatat dan mengerjakan soal saja.

Hal ini juga di dukung oleh observasi yang menyatakan bahwa pembelajaran yang dilakukan oleh guru masih bersifat berpusat pada guru (teacher centered) dan pengajaran langsung yang berupa metode ceramah maupun pemberian tugas dan soal, sehingga siswa hanya menerima informasi selama kegiatan pembelajaran berlangsung (Derlina \& Pane, 2016; Zulva, 2016). Sebagai contohnya, mata pelajaran fisika yang ditetapkan sekolah SMA Negeri 10 Medan adalah 70, tetapi hanya 15 orang siswa saja di tiap kelas yang mampu mencapai nilai di atas 70 dan 25 orang masih di bawah 70. Maka, jelaslah hasil belajar fisika siswa masih rendah. Hal ini di dukung oleh sebuah penelitian yang menyatakan bahwa rendahnya hasil belajar aspek kognitif peserta didik dikarenakan peserta didik belum terlibat secara aktif dalam proses pembelajaran (Poniman, 2016). Hal ini ditunjukkan saat mengikuti proses 
pembelajaran di kelas, peserta didik ada yang tidak memperhatikan saat guru menerangkan pelajaran, suka menggangu teman, bermain handphone dan berbicara dengan teman sebangkunya.

Berdasarkan kenyataan tersebut, dalam pembelajaran fisika perlu diterapkan suatu model pembelajaran yang sesuai. Salah satu alternatif model pembelajaran yang memungkinkan diterapkan adalah model pembelajaran Kooperatif tipe Group Investigation (GI). Model pembelajaran kooperatif tipe $G I$ adalah sebuah model yang tidak mengharuskan siswa menghafal fakta dan rumus-rumus tetapi sebuah model yang membimbing para siswa mengidentifikasi topik, merencanakan investigasi di dalam kelompok, melaksanakan penyelidikan, melaporkan, dan mempresentasikan hasil penyelidikannya.

Group Investigation membantu siswa memahami topik-topik pembelajaran, secara aktif mendorong siswa untuk belajar serta bagaimana mendapatkan pengetahuan dari penyelidikan yang siswa lakukan. Para siswa termotivasi sehingga dapat mendeskripsikan topik yang sulit dengan mudah untuk dipahami, memungkinkan mereka untuk meningkatkan pengetahuan mereka dan melakukan percobaan dengan keahlian mereka (Amelia \& H, 2016; Chusni et al., 2017; Simsek, 2012).

Siswa bukan hanya dituntut untuk bekerja sama didalam Group Investigation, tetapi juga saling membantu merencanakan topik yang akan dipelajari maupun prosedur investigatif yang digunakan. Dalam kegiatan Group Investigation, peserta didik secara aktif ikut dalam perencanaan, pelaksanaan, penyelidikan, dan kemudian mempresentasikan penemuan mereka kepada teman lainnya. Hal ini menuntut siswa untuk berpikir tinggi dan kritis (Akçay \& Doymuş, 2012; Billy, Hendriyanti, \& Resti, 2017; Sasongko, 2014).
Guru yang menggunakan pendekatan Group Investigation biasanya membagi kelasnya menjadi kelompok-kelompok heterogen yang masing-masing beranggota lima atau enam orang. Siswa memilih topik-topik untuk dipelajari, melakukan investigasi mendalam terhadap sub-sub topik yang dipilih, dan kemudian menyiapkan dan mempresentasikan laporan kepada seluruh kelas. Peserta didik dalam kelompok juga diberi kesempatan untuk menentukan cara menyelesaikan tugas. Peserta didik juga melakukan interpretasi hasil penyelidikan yang mungkin berbeda satu dengan yang lainnya sehingga memperoleh suatu pemikiran utuh yang kemudian mereka tuangkan ke dalam penyelesaian tugas kelompok. Aspek rasa sosial dari kelompok serta pertukaran intelektual dapat bertindak sebagai sumber-sumber penting bagi siswa untuk belajar (Saputra, 2016).

Salah satu metode yang dapat digunakan dalam Group Investigation adalah metode KWL (Know, Want to Know, Learn). Metode KWL adalah suatu cara penyajian bahan pelajaran dimana akan memberikan kepada siswa yang bertujuan supaya siswa membaca dan berperan aktif selama sebelum, saat dan sesudah membaca (Nurlaela \& Suwono, Hadi, 2017; Santoso, 2015). Metode ini terdiri dari tiga langkah-langkah dasar yaitu mengakses pengetahuan sebelumnya, menentukan apa yang ingin diketahui dan mengingat kembali apa yang dipelajari (Zouhor, Bogdanović, \& Segedinac, 2016). Melalui proses belajar yang mengalami sendiri, menemukan sendiri, secara berkelompok seperti bermain, maka anak menjadi senang, sehingga tumbuhlah minat untuk belajar, khususnya belajar Fisika (Mustari, 2015).

\section{METODE PENELITIAN}

Penelitian dilaksanakan di SMA Negeri 21 Medan untuk mengetahui ada atau tidaknya pengaruh model 
pembelajaran model pembelajaran kooperatif tipe Group Investigation (GI) dengan metode Know-Want-Learn (KWL) terhadap hasil belajar siswa kelas XI semester II pada materi pokok Fluida Dinamis T.P. 2016/2017.

Populasi dalam penelitian ini adalah seluruh siswa kelas XI IPA SMA Negeri 21 Medan Tahun Pembelajaran 2016/2017 yang berjumlah 136 siswa dan terdistribusi dalam 4 kelas.

Pengambilan sampel dilakukan dengan teknik cluster random sampling. Dari 4 kelas yang menjadi sampel penelitian ini, 2 kelas yaitu kelas eksperimen diterapkan model pembelajaran kooperatif tipe Group Investigation (GI) dengan metode Know-Want-Learn (KWL) dan kelas kontrol diterapkan pembelajaran konvensional. Adapun kelas yang dijadikan sebagai kelas eksperimen adalah kelas XI IPA - 3 dengan jumlah siswa 34 orang, dan kelas kontrolnya adalah kelas XI IPA - 4 dengan jumlah siswa 34 orang.

Jenis penelitian ini adalah quasi experiment (eksperimen semu) yaitu penelitian yang dimaksudkan untuk mengetahui ada tidaknya pengaruh dari sesuatu yang dikenakan pada subjek yaitu siswa.

Tabel 1 Pre-test and Post-test Design

\begin{tabular}{llll} 
Kelas & Pretest & Perlakuan & Postest \\
Eksperimen & $\mathrm{T}_{1}$ & $\mathrm{X}_{1}$ & $\mathrm{~T}_{2}$ \\
Kontrol & $\mathrm{T}_{1}$ & $\mathrm{X}_{2}$ & $\mathrm{~T}_{2}$ \\
& & & \\
\hline
\end{tabular}

Keterangan :

$\mathrm{T}_{1}=$ Tes awal $($ Pre-test $)$

$\mathrm{T}_{2}=$ Tes akhir (Post-test)

$\mathrm{X}_{1}=$ Perlakuan 1 yang diberikan pembelajaran dengan menggunakan model pembelajaran kooperatif tipe Group Investigation $(G I)$ dengan metode Know-Want-Learn (KWL)

$\mathrm{X}_{2}=$ Perlakuan 2 yang diberikan dengan pembelajaran konvensional

Pengujian dari Validitas ramalan dilaksanakan dengan mengujikan soal yang telah dibuat kepada siswa sekolah lain yang sudah pernah mempelajari materi Fluida Dinamis. Tes diberikan kepada siswa kelas XI SMA Negeri 15 Medan.

Pengujian normalitas data digunakan untuk mengetahui apakah data kontinu tersebut berdistribusi normal sehingga analisis dengan validitas, reliabilitas, uji t, korelasi, dan regresi dapat dilaksanakan.

Pemeriksaan uji homogenitas varian bertujuan untuk mengetahui apakah data sampel memiliki variansi yang homogen atau tidak.

Uji $\mathrm{t}$ satu pihak digunakan untuk mengetahui perbedaan prestasi hasil belajar siswa yang diajarkan secara konvensional dengan siswa yang diajarkan dengan model pembelajaran kooperatif tipe Group Investigation (GI) dengan Metode Know-Want-Learn $(K W L)$. Hipotesis yang diuji berbentuk :

$$
\begin{aligned}
& \mathrm{H}_{\mathrm{o}}: \mu_{1}=\mu_{2} \\
& \mathrm{Ha}: \mu_{1}>\mu_{2}
\end{aligned}
$$

$\mu_{1}=$ skor rata-rata hasil belajar kelas eksperimen

$\mu_{2}=$ skor rata-rata hasil belajar kelas kontrol

Keterangan :

$\mu_{1}=\mu_{2} \quad$ :Hasil belajar siswa pada kelas eksperimen sama dengan hasil belajar siswa pada kelas kontrol.

$\mu_{1}>\mu_{2} \quad$ :Hasil belajar siswa pada kelas eksperimen lebih besar dari pada hasil belajar siswa pada kelas kontrol.

Bila data penelitian berdistribusi normal dan homogen maka untuk menguji hipotesis menggunakan uji $t$ dengan rumus, yaitu :

$$
\mathrm{t}=\frac{\bar{x}_{1}-\bar{x}_{2}}{S \sqrt{\frac{1}{n_{1}}+\frac{1}{n_{2}}}}
$$

Dimana $S$ adalah varians gabungan yang dihitung dengan rumus :

$$
S^{2}=\frac{\left(n_{1}-1\right) S_{1}{ }^{2}+\left(n_{2}-1\right) S_{2}{ }^{2}}{n_{1}+n_{2}-2}
$$

Kriteria pengujian adalah : terima $\mathrm{H}_{0}$ jika $-t_{(1-\alpha)}<t<t_{(1-\alpha)}$ dimana $t_{(1-\alpha)}$ 
didapat dari daftar distribusi $\mathrm{t}$ dengan $\mathrm{dk}$ $=\mathrm{n}_{1}+\mathrm{n}_{2}-2$ dan $\alpha=0,05$. Untuk harga $\mathrm{t}$ lainnya $\mathrm{H}_{\mathrm{o}}$ ditolak dan $\mathrm{Ha}$ diterima yakni ada pengaruh hasil belajar siswa dengan menggunakan model pembelajaran kooperatif tipe Group Investigation (GI) dengan metode Know-Want-Learn $(K W L)$.

\section{HASIL DAN PEMBAHASAN Hasil Penelitian}

Data yang dideskripsikan pada penelitian ini adalah data hasil belajar siswa pada materi pokok fluida dinamis yang diberi perlakuan berbeda. Kelas eksperimen dengan model pembelajaran kooperatif tipe Group Investigation dengan metode Know-Want-Learn (KWL) dan kelas kontrol dengan pembelajaran konvensional.

Pada awal penelitian kedua kelas diberikan tes uji kemampuan awal (pretes) untuk mengetahui kemampuan awal siswa pada kedua kelas tersebut. Berdasarkan data hasil penelitian diperoleh nilai rata-rata pretes siswa pada kelas eksperimen sebesar 26,86 dengan standar deviasi 11,78. Sedangkan pada kelas kontrol diperoleh nilai rata-rata pretes siswa sebesar 26,86 dengan standar deviasi 12,22. Selanjutnya kelas eksperimen dan kelas kontrol diberikan perlakuan yang berbeda. Pada kelas eksperimen menggunakan model pembelajaran kooperatif tipe Group Investigation dengan metode Know-WantLearn (KWL) dan kelas kontrol dengan pembelajaran konvensional. Setelah kedua kelas diberikan perlakuan, masingmasing kelas diberi postes untuk melihat adanya pengaruh ketika diberi perlakuan pembelajaran yang berbeda. Dari data postes kedua kelas diperoleh nilai ratarata postes untuk kelas eksperimen sebesar 74,7 dan nilai rata-rata postes kelas kontrol sebesar 63.53 yang ditunjukkan pada Gambar 1 di bawah ini.



Gambar 1. Data Pretes dan Postes Kelas Eksperimen dan Kelas Kontrol

Berdasarkan hasil uji normalitas dengan menggunakan uji Lilliefors untuk kedua sampel diperoleh bahwa nilai pretes dan postes berdistribusi normal seperti ditunjukkan pada Tabel 2.

Tabel 2 Hasil Uji Normalitas Data Pretes dan Postes

\begin{tabular}{|c|c|c|c|}
\hline \multicolumn{3}{|c|}{ kedua kelas } & \multirow{3}{*}{ Kesimpulan } \\
\hline Kelas & \multicolumn{2}{|c|}{ Data Pretes } & \\
\hline & Lhitung & $\mathbf{L}_{\text {tabel }}$ & \\
\hline $\begin{array}{c}\text { Eksperi } \\
\text { men }\end{array}$ & 0,1308 & 0,15 & Normal \\
\hline \multirow[t]{3}{*}{ Kontrol } & 0,1018 & & Normal \\
\hline & \multicolumn{2}{|c|}{ Data Pretes } & \\
\hline & Lhitung & $\mathbf{L}_{\text {tabel }}$ & \\
\hline $\begin{array}{c}\text { Eksperi } \\
\text { men }\end{array}$ & 0,1109 & 0,15 & Normal \\
\hline Kontrol & 0,1344 & & Normal \\
\hline
\end{tabular}

Tabel 2 menunjukkan bahwa $\mathrm{L}_{\text {hitung }}<$ $\mathrm{L}_{\text {tabel }}$ baik kelas eksperimen dan kelas kontrol pada data pretes dan postes dengan $\alpha=0,05$. Berdasarkan hasil perhitungan $\mathrm{L}_{\text {hitung }}$ dan $\mathrm{L}_{\text {tabel }}$ tersebut, maka dapat disimpulkan bahwa data kedua kelas sampel berdistribusi normal.

Pengujian homogenitas data pretes dan data postes pada kelas eksperimen dan kelas kontrol dilakukan dengan uji kesamaan dua varians untuk mengetahui apakah kelompok sampel berasal dari populasi yang homogen atau tidak. Hasil uji homogenitas data yang diperoleh ditunjukkan pada Tabel 3.

Tabel 3 Hasil Uji Homogenitas pada Kedua Kelas

\begin{tabular}{rccc}
\hline Data & $\mathrm{F}_{\text {hitung }}$ & $\mathrm{F}_{\text {tabel }}$ & Kesimpulan \\
\hline Pretes & 1,08 & 1,792 & Homogen \\
\hline Postes & 1,686 & 1,792 & \\
\hline
\end{tabular}

Dengan kriteria pengujian homogenitas $F_{\text {hitung }}<F_{\text {tabel }}$ maka dapat dinyatakan 
bahwa kedua sampel memiliki varians yang sama (Homogen) atau dapat mewakili populasi yang ada atau berasal dari populasi yang sama.

Hasil uji hipotesis untuk postes menggunakan uji t pada taraf signifikan $\alpha=0,05$, diperoleh $t_{\text {hitung }}>t_{\text {tabel }}(3,5>$ 1,669). Hasil uji hipotesis terhadap hasil postes ditunjukkan pada Tabel 4. Berdasarkan Tabel 4, didapat $t_{\text {hitung }}>t_{\text {tabel, }}$ dapat disimpulkan bahwa ada pengaruh model pembelajaran kooperatif tipe Group Investigation (GI) dengan metode Know-Want-Learn (KWL) terhadap hasil belajar siswa.

Tabel 4. Perhitungan Uji Beda pada Kelas Eksperimen dan Kelas Kontrol

\begin{tabular}{ccccc}
\hline Data & $\mathrm{t}_{\text {hitung }}$ & $\mathrm{t}_{\text {tabel }}$ & & Kesimpulan \\
\hline Pretes & 0,0000 & \multirow{2}{*}{1,669} & & $\begin{array}{c}\text { Tidak ada } \\
\text { perbedaann }\end{array}$ \\
\cline { 5 - 5 } \cline { 5 - 5 } Postes & 3368 & & & $\begin{array}{c}\text { Ada } \\
\text { perbedaan }\end{array}$ \\
\hline
\end{tabular}

Hasil pada Tabel 4 diperoleh bahwa nilai postes $t_{\text {hitung }}>t_{\text {tabel }}$ yaitu 3,5 > 1,998 maka $\mathrm{H}_{0}$ ditolak dan $\mathrm{H}_{\mathrm{a}}$ diterima, sehingga diperoleh bahwa hasil belajar siswa pada kelas eksperimen lebih besar daripada hasil belajar siswa kelas kontrol, berarti ada pengaruh penerapan model pembelajaran kooperatif tipe Group Investigation dengan metode Know-WantLearn (KWL) terhadap hasil belajar siswa pada materi pokok fluida dinamis kelas XI semester II di SMA Negeri 21 Medan T.P. 2016/2017.

Hasil belajar sikap dinilai oleh observer selama proses pembelajaran. Aspek yang dinilai yaitu kejujuran, sopan santun, percaya diri, tanggung jawab, dan disiplin. Hasil penilaian sikap kelas eksperimen dapat ditunjukkan pada Tabel 5 di bawah ini.

Tabel 5 Penilaian Sikap Kelas Eksperimen

\begin{tabular}{cccc}
\hline No & Pertemuan & $\begin{array}{c}\text { Rata }- \\
\text { Rata }\end{array}$ & Kriteria \\
\hline 1 & Pertemuan I & 48,82 & $\begin{array}{c}\text { Kurang } \\
\text { Baik }\end{array}$ \\
\hline 2 & Pertemuan II & 59,41 & $\begin{array}{c}\text { Cukup } \\
\text { Baik }\end{array}$ \\
\hline 3 & Pertemuan III & 75,3 & Baik \\
\hline
\end{tabular}

$$
\text { Keterangan : } \quad \begin{aligned}
& <50=\text { Kurang Baik; } \\
& 50-69=\text { Cukup Baik } \\
& 70-100=\text { Baik }
\end{aligned}
$$

Hasil belajar keterampilan dinilai oleh observer selama proses pembelajaran. Aspek yang dinilai yaitu cara merangkai alat, pengamatan, data yang diperoleh, dan cara menarik kesimpulan. Hasil penilaian keterampilan kelas eksperimen ditampilkan pada tabel 6 di bawah ini.

Tabel 6. Penilaian Keterampilan Kelas Eksperimen

\begin{tabular}{cccc}
\hline No & Pertemuan & $\begin{array}{c}\text { Rata- } \\
\text { Rata }\end{array}$ & Kriteria \\
\hline 1 & Pertemuan I & 80,1 & Baik \\
\hline 2 & Pertemuan II & 80,88 & Baik \\
\hline 3 & Pertemuan III & 81,13 & Baik \\
\hline Keterangan : & $<50=$ Kurang Baik; \\
& $50-69=$ Cukup Baik; \\
& $70-100=$ Baik
\end{tabular}

Observasi bertujuan untuk mengamati aktivitas belajar siswa selama pembelajaran dengan model pembelajaran kooperatif tipe Group Investigation (GI) dengan metode Know-Want-Learn (KWL) di kelas eksperimen. Observasi dilakukan oleh dua observer yaitu Muhammad Umar Arisandi dan Sutria Putri Wahyuti. Jumlah siswa pada kelas eksperimen berjumlah 34 orang, maka peneliti membagi siswa secara heterogen menjadi 6 kelompok.

Adapun perincian pencapaian aktivitas siswa pada kelas eksperimen dapat dilihat pada Tabel 7 berikut.

Tabel 7 Penilaian Aktivitas Kelas Eksperimen

\begin{tabular}{cccc}
\hline No & Pertemuan & $\begin{array}{c}\text { Rata- } \\
\text { Rata }\end{array}$ & Kriteria \\
\hline 1 & Pertemuan I & 60,3 & Aktif \\
\hline 2 & Pertemuan II & 69,54 & Aktif \\
\hline 3 & Pertemuan III & 79,41 & Aktif \\
\hline
\end{tabular}

$$
\text { Keterangan : } \quad \begin{array}{ll}
<40 & =\text { Kurang Aktif; } \\
40-59 & =\text { Cukup Aktif } \\
60-79 & =\text { Aktif; } \\
80-100 & =\text { Sangat Aktif }
\end{array}
$$

\section{Pembahasan}

Berdasarkan hasil penelitian yang dilakukan setelah kedua kelas diberi 
perlakuan yang berbeda yaitu pada kelas eksperimen menggunakan model pembelajaran kooperatif tipe Group Investigation dengan metode Know-WantLearn (KWL) dan pada kelas kontrol menggunakan pembelajaran konvensional terdapat perbedaan hasil belajar. Adanya perbedaan hasil belajar tersebut disebabkan oleh kelebihan model pembelajaran kooperatif tipe GI yang tidak mengharuskan siswa menghafal fakta tetapi sebuah model yang membimbing para siswa untuk menemukan sendiri pengetahuan melalui masalah yang diberikan. Hal ini juga didukung oleh (Sasongko, 2014) bahwa model kooperatif tipe GI membimbing para siswa mengidentifikasi topik, merencanakan investigasi di dalam kelompok, melaksanakan penyelidikan, melaporkan, dan mempresentasikan hasil penyelidikannya.

Berdasarkan hasil penelitian yang dilakukan setelah kedua kelas diberi perlakuan yang berbeda yaitu pada kelas eksperimen menggunakan model pembelajaran kooperatif tipe Group Investigation dengan metode Know-WantLearn (KWL) dan pada kelas kontrol menggunakan pembelajaran konvensional yang masing-masing kelas diberi postes untuk melihat adanya perbedaan akibat diberikan perlakuan pembelajaran yang berbeda. Dari data postes kedua kelas diperoleh nilai rata-rata postes untuk kelas eksperimen sebesar 74,7 dan nilai ratarata postes kelas kontrol sebesar 63,53. Hasil uji normalitas dan homogenitas untuk kedua sampel diperoleh bahwa nilai postes berdistribusi normal dan berasal dari populasi yang homogen. Hasil uji hipotesis untuk postes menggunakan uji $\mathrm{t}$ diperoleh $t_{\text {hitung }}>t_{\text {tabel }}(3,5>1,669)$ yang berarti bahwa ada pengaruh penerapan model pembelajaran kooperatif tipe Group Investigation dengan metode Know-Want-Learn (KWL) terhadap hasil belajar siswa pada materi pokok fluida dinamis kelas XI semester II di SMA Negeri 21 Medan T.P. 2016/2017.

Peningkatan aktivitas pada kelas eksperimen juga terlihat pada kelas eksperimen pada pertemuan I-II dan pertemuan II-III masing-masing 7,6\% dan $7,13 \%$ dan berkriteria aktif. Peningkatan afektif siswa dalam kegiatan belajar mengajar juga mengalami peningkatan. Pada kelas eksperimen sikap siswa berkategori baik dengan nilai rata-rata sebesar 61,17. Begitu juga dengan penilaian psikomotorik siswa dalam kegiatan belajar mengajar juga mengalami peningkatan dengan nilai rata - rata sebesar 80,7.

Hasil penelitian menunjukkan adanya pengaruh dari model pembelajaran kooperatif tipe Group Investigation dengan metode Know-Want-Learn (KWL) dibandingkan dengan pembelajaran konvensional terhadap hasil belajar siswa pada materi pokok fluida dinamis kelas XI semester II di SMA Negeri 21 Medan T.P 2016/2017. Hal ini dapat dibuktikan dengan adanya data hasil belajar siswa pada kelas eksperimen lebih baik daripada hasil belajar siswa pada kelas kontrol. Data tersebut membuktikan bahwa hasil belajar siswa dengan menerapkan model pembelajaran kooperatif tipe Group Investigation dengan metode Know-Want-Learn (KWL) lebih baik daripada hasil belajar siswa dengan menerapkan pembelajaran konvensional.

Adanya peningkatan hasil belajar yang diperoleh disebabkan karena model pembelajaran kooperatif tipe Group Investigation sangat cocok untuk pelajaran sains karena mendorong siswa untuk belajar dan melakukan penelitian ilmiah (Akçay \& Doymuş, 2012). Hasil penelitian tersebut juga diperoleh karena model pembelajaran kooperatif tipe Group Investigation dirancang untuk membawa siswa secara langsung ke dalam proses ilmiah melalui investigasi kelompok siswa terhadap materi yang 
diajarkan dan percobaan yang dilakukan secara langsung yang dimana mereka saling berinteraksi dalam mendiskusikan dan menganalisis hasil penyelidikan terhadap percobaan yang telah dilakukan dan kemudian mendapatkan informasi baru dan kesimpulan dari pembelajaran yang berlangsung. Model pembelajaran ini benar-benar mengajak siswa menjadi aktif (Iswardati, 2016).

Selanjutnya dengan adanya metode Know-Want-Learn (KWL) dalam proses pembelajaran, dapat mengevaluasi pembelajaran yang telah dilakukan oleh siswa. Siswa didorong untuk mengemukakan pengetahuan awal yang telah mereka miliki sesuai dengan permasalahan yang diajukan oleh guru pada kolom Know (K), dan menetapkan hal-hal apa saja yang ingin mereka pelajari selama proses pembelajaran pada kolom Want (W) dan pada akhir pembelajaran, para siswa menyimpulkan sendiri hal-hal apa saja yang telah mereka pelajari pada kolom Learn (L) sesuai dengan hal-hal yang ingin mereka pelajari pada kolom W sebelumnya. Dan hal ini akan mempermudah guru untuk meninjau dan mengevaluasi perkembangan siswa dalam proses pembelajaran yang telah berlangsung, dan bukan hanya guru saja, dari lembar KWL ini siswa pun mampu mengetahui dan mengevaluasi sendiri hal-hal baru apa saja yang telah mereka peroleh di akhir pembelajaran.

Maka dari penelitian ini dapat disimpulkan bahwa ada pengaruh model pembelajaran kooperatif tipe Group Investigation dengan metode Know-WantLearn (KWL) terhadap hasil belajar siswa pada materi pokok fluida dinamis kelas XI semester II di SMA Negeri 21 Medan T.P 2016/2017.

Penerapan model pembelajaran kooperatif tipe Group Investigation dengan metode Know-Want-Learn (KWL) yang telah dilakukan oleh penulis belum mendapatkan hasil yang optimal karena pada pembelajaran masih ada beberapa kendala yang dihadapi oleh penulis. Kendala itu antara lain yaitu tidak semua siswa berperan aktif dalam kegiatan kelompok, sehingga kegiatan kelompok selalu didominasi oleh siswa yang sama, kondisi kelas yang ribut dalam hal pembagian kelompok dan pembacaan hasil diskusi dapat mengurangi efektivitas dalam belajar sehingga ketersediaan waktu dalam Rencana Pelaksanaan Pembelajaran (RPP) tidak sesuai dengan pelaksanaannya. Selain itu, peneliti juga mengalami kendala dalam mengawasi siswa dalam setiap kelompok karena observer yang dilibatkan masih terbatas yaitu dua orang dimana siswa yang harus diamati cukup banyak yaitu 34 orang.

\section{SIMPULAN}

Simpulan penelitian ini didasarkan pada temuan dari data-data hasil penelitian, sistematika sajiannya dilakukan dengan memperhatikan tujuan penelitian yang telah dirumuskan. Adapun simpulan yang diperoleh, bahwa ada pengaruh model pembelajaran kooperatif tipe Group Investigation dengan metode Know-Want-Learn (KWL) terhadap hasil belajar siswa pada materi pokok Fluida dinamis. Dimana hasil belajar siswa dengan menggunakan model pembelajaran kooperatif tipe Group Investigation dengan metode Know-WantLearn (KWL) lebih baik dibandingkan dengan model pembelajaran konvensional sehingga dapat dikatakan ada pengaruh pada model pembelajaran kooperatif tipe Group Investigation dengan metode Know-Want-Learn (KWL) terhadap hasil belajar siswa pada materi pokok Fluida Dinamis.

\section{DAFTAR PUSTAKA}

Akçay, N. O., \& Doymuş, K. (2012). The Effects of Group Investigation and Cooperative Learning Techniques Applied in Teaching Force and 
Motion Subjects on Students' Academic Achievements. Journal of Educational Sciences Research, 2(1), 109-123.

Amelia, R., \& H, S. K. (2016). The Influence of V Diagram Procedural Scaffolding in Group Investigation Towards Students with High and Low Prior Knowledge. Jurnal Pendidikan IPA Indonesia, 5(1), 109-115.

Billy, M., Hendriyanti, M. E., \& Resti, V. D. A. (2017). Profil Kemampuan Berpikir Kritis Siswi Melalui Model Pembelajaran Group Investigation (GI) pada Konsep Sistem Gerak. Biodidaktika, 12(2), 25-44.

Chusni, M. M., Mahardika, A., Sayekti, I. C., Setya, W., Magelang, U. M., \& Surakarta, U. M. (2017). The Profile of Student Activities in Learning Basic Natural Science Concepts through The Contextual Teaching and Learning ( CTL ) Approach with Group Investigation ( GI ) Model. Jurnal Penelitian dan Pembelajaran IPA, 3(1), 1-10.

Derlina, \& Pane, K. I. (2016). Kemampuan Pemecahan Masalah Siswa SMA dalam Model Pembelajaran Berbasis Masalah dengan Metode Know-Want-Learn (KWL). Jurnal Saintech, 8(3), 1-10.

Erlinda, N. (2017). Peningkatan Aktivitas dan Hasil Belajar Siswa melalui Model Kooperatif Tipe Team Game Tournament pada Mata Pelajaran Fisika di SMK. Tadris: Jurnal Keguruan Dan Ilmu Tarbiyah, 2(1), 47-52.

Gumrowi, A. (2016). Strategi Pembelajaran Melalui Pendekatan Kontekstual dengan Cooperative Learning untuk Meningkatkan Hasil Belajar Gelombang Siswa Kelas XII MAN 1 Bandar Lampung. Jurnal Ilmiah Pendidikan Fisika Al-BiRuNi, 5(2), 183-191.

Iswardati. (2016). The Implementation of
Group Investigation to Improve the Students ' Speaking Skill. Dinamika Ilmu, 16(2), 245-261.

Komikesari, H. (2016). Peningkatan Keterampilan Proses Sains dan Hasil Belajar Fisika Siswa pada Model Pembelajaran Kooperatif Tipe Student Team Achievement Division. Tadris: Jurnal Keguruan Dan Ilmu Tarbiyah, 1(1), 15-22.

Mustari, M. (2015). Pengaruh Penggunaan Media Gambar Lewat Komputer terhadap Hasil Belajar Fisika pada Siswa Kelas X SMA Negeri 3 Makassar. Jurnal Ilmiah Pendidikan Fisika Al-BiRuNi, 4(2), 269-280.

Nurlaela, N., \& Suwono, Hadi, S. (2017). Pengaruh Pembelajaran Inkuiri Sains Berbantuan Know, Want, Learn ( Kwl ) terhadap Hasil Belajar Kognitif Biologi. Jurnal Pendidikan:teori, Penelitian, Dan Pengembangan, 2(2), 186-191.

Poniman. (2016). Upaya Peningkatan Aktivitas dan Hasil Belajar Fisika dengan Metode Praktikum pada Siswa Kelas XI IPA MAN 1 Kalianda Lampung Selatan. Jurnal Ilmiah Pendidikan Fisika Al-Biruni, 5(2), 257-264.

Santoso, A. B. (2015). Pengaruh Metode Pembelajaran KWL ( Know, Want, Learn ) Terhadap Hasil Belajar Siswa di SMK Negeri 2 Surabaya. Jurnal Pendidikan Teknik Elektro, 4(3), 725-731.

Saputra, W. N. E. (2016). Jurnal Konseling dan Pendidikan. Jurnal Konseling Dan Pendidikan, 4(1), 3945.

Sasmita, P. R. (2017). Penerapan metode inkuiri terbimbing menggunakan media kit fisika: upaya meningkatkan aktivitas dan hasil belajar fisika siswa. Jurnal Ilmiah Pendidikan Fisika Al-Biruni, 6(1), 95-102.

Sasongko, H. W. (2014). Tinjauan 
Keefektifan GI Menggunakan Alat Peraga Manipulatif dari Aspek Prestasi Belajar Bangun Ruang Sisi Datar dan Apresiasi terhadap Matematika SMP. Pythagoras: Jurnal Pendidikan Matematika Volume, 9(2), 136-146.

Simsek, U. (2012). The Effects of Reading-Writing-Presentation and Group Investigation Methods on Students 'Academic Achievements in Citizenship Lessons. Journal of Educational Sciences Research, 2(2), 189-201.

Wijayanti, W., Maharta, N., \& Suana, W. (2017). Pengembangan Perangkat Blended Learning Berbasis Learning Management System pada Materi Listrik Dinamis. Jurnal Ilmiah Pendidikan Fisika Al-Biruni, 6(1), 1-
12.

Yusuf, M. T., \& Amin, M. (2016). Pengaruh Mind Map dan Gaya Belajar terhadap Hasil Belajar Matematika Siswa. Tadris: Jurnal Keguruan Dan Ilmu Tarbiyah, 1(1), 85-92.

Zouhor, Z., Bogdanović, I., \& Segedinac, M. (2016). Effects of the KnowWant-Learn Strategy on Primary School Students 'Metacognition and Physics Achievement. Journal of Subject Didactics, 1(1), 39-49.

Zulva, R. (2016). Hubungan Antara Keterampilan Berpikir Dalam Pembelajaran Kooperatif Menggunakan Constructive Feedback. Jurnal Ilmiah Pendidikan Fisika Al-Biruni, 5(1), 61-69. 